\title{
Redescription of the enigmatic long-tailed rat Sigmodontomys aphrastus (Cricetidae: Sigmodontinae) with comments on taxonomy and natural history
}

\author{
Christy M. McCain*, Robert M. Timm, and Marcelo Weksler
}

(CMM) Natural History Museum and Department of Ecology \& Evolutionary Biology, University of Kansas, Lawrence, Kansas 66045-7561, U.S.A., Current address: National Center for Ecological Analysis \& Synthesis (NCEAS), 735 State Street, Suite 300, Santa Barbara, California 93101, U.S.A., e-mail: mccain@nceas.ucsb.edu;

(RMT) Natural History Museum and Department of Ecology \& Evolutionary Biology, University of Kansas, Lawrence, Kansas 66045-7561, U.S.A., e-mail: btimm@ku.edu; (MW) Institute of Arctic Biology and University of Alaska Museum, University of Alaska Fairbanks, Fairbanks, Alaska 99775, U.S.A., e-mail: mweksler@amnh.org

Abstract. - Sigmodontomys aphrastus, the long-tailed rat, is an exceedingly rare rodent species from montane regions of Central and South America of which very little is known ecologically or systematically. It has been variously placed in the genera Oryzomys, Nectomys, and Sigmodontomys based on the five previously known specimens. Two new individuals were collected in northwestern Costa Rica's Cordillera de Tilarán. These new specimens and the other five known specimens are used to redescribe the species, detail measurements of external and cranial morphology, and compare $S$. aphrastus to similarly appearing sympatric species (Nephelomys albigularis and $N$. devius) and proposed closely related species (Sigmodontomys alfari, Mindomys hammondi, and Melanomys caliginosus). New ecological data is presented and the general knowledge of its natural history is summarized. The phylogenetic relatedness of S. aphrastus with purported sister taxa remains unresolved until combined molecular and morphological analyses are conducted.

Resumen.-Sigmodontomys aphrastus, la rata de cola larga, es una especie rara de rodedor de las montañas de America Central y Sur de la cual se conoce muy poco acerca de su ecología y sistemática. Esta especie ha sido clasificada en el género Oryzomys, Nectomys, y Sigmodontomys basado en solo cinco especímenes. Dos nuevos individuos fueron recolectados en el noreste de Costa Rica en la Cordillera de Tilarán. Estos dos nuevos especímenes y junto con los cinco anteriores son usados a describir nuevamente la especie, detallar sus medidas morfométricas externas y craneales, y comparar $S$. aphrastus con especies simpátricas similares (Nephelomys albigularis and $N$. devius) y especies que han sido propuestas como dentro del mismo clado (Sigmodontomys alfari, Mindomys hammondi, y Melanomys caliginosus). Presentamos nuevos datos ecológicos y resumimos el conocimiento de su historia natural. La relación filogenética de $S$. aphrastus con las especies propuestas como del mismo clado no sera resuelto hasta que analisis moleculares y morfologicos sean llevados a cabo.

* Corresponding author. 
One of the most poorly known rodents in the Western Hemisphere is the longtailed rat Sigmodontomys aphrastus (Harris 1932). Little is known about its natural history, ecology, and systematics, and that is reflected in its complicated taxonomic history. Harris (1932) described this distinctive species as a member of Oryzomys Baird, 1857 based on the then single known specimen but made no comparisons to other species. Hershkovitz (1944) transferred it to the genus Nectomys Peters, 1861 and suggested that it closely resembled Alfaro's rat, Nectomys alfari (=Sigmodontomys alfari J. A. Allen, 1897). Later, Hershkovitz (1948) associated it with Nectomys hammondi [= Mindomys hammondi (Thomas, 1913)]. Hall \& Kelson (1959:565) assigned aphrastus to their Oryzomys devius-group (i.e., Nephelomys) but reported that the "systematic position of this 'species' is doubtful." In the second edition of Mammals of North America, Hall (1981:618) listed aphrastus as a species of Oryzomys "provisionally placed between $O$. albigularis and $O$. capito." $\mathrm{He}$ reported it as known only from the type locality and apparently considered the taxonomic status uncertain because quotation marks were placed around the word species. [Hall's use of $O$. albigularis corresponds to the species we now recognize as Nephelomys devius (Bangs, 1902) and his use of $O$. capito corresponds to the species we now recognize as Transandinomys talamancae (J. A. Allen, 1891); see Weksler et al. 2006 for updated nomenclature of oryzomyine genera]. Ray (1962), in an unpublished dissertation on fossil Caribbean oryzomyines, associated aphrastus with Sigmodontomys alfari. This position was followed by Musser \& Carleton (1993, 2005), who provisionally assigned aphrastus to the genus Sigmodontomys. Recently, Weksler (2006) recovered $S$. aphrastus as a member of a clade that also included Sigmodontomys alfari and Melanomys caliginosus (Tomes,
1860) using cladistic analyses of morphological characters (with and without nuclear sequence data). Although phylogenetic relationships within this clade varied among analytic permutations, $S$. aphrastus was recovered as sister species to $M$. caliginosus in the total evidence analysis of morphological and molecular data.

This taxonomic uncertainty is perhaps due to the paucity of specimens, lack of adequate description, and meager ecological information available for the species. Sigmodontomys aphrastus had been known from only five specimens. Harris (1932) described the species based on a single adult female collected in 1931 by Austin Smith from the Pacific foothills of Costa Rica's Cordillera de Talamanca at $1220 \mathrm{~m}$. The holotype (UMMZ 62875) is represented by a study skin and a broken, inadequately cleaned skull (see Fig. 4). P. Menas took the second specimen, an adult male, in northwestern Ecuador on Volcán Pichincha in 1953. This individual is in the Museum of Comparative Zoology at Harvard University and was first identified as Sigmodontomys alfari, but later determined to be $O$. aphrastus by Guy G. Musser (pers. comm.). In 1980, Ronald H. Pine and Robert J. Izor caught an adult male and an immature male in the Cordillera de Chiriquí of western Panama (Méndez 1993; R. H. Pine, pers. comm.). The fifth specimen is an adult female caught later in 1980 by Robert S. Voss on the Pacific slopes of Volcán Pichincha in Ecuador (Musser \& Williams 1985, Voss 1988).

Our recent fieldwork in the Monteverde Cloud Forest Reserve in northwestern Costa Rica resulted in the collection of two new specimens of $S$. aphrastus. Here, we redescribe the species, report external and cranial measurements, and present new ecological data. Additionally, we compare $S$. aphrastus with the sympatric and similar appearing Nephelomys albigularis and $N$. devius, with taxa it has 
been associated with previously, Sigmodontomys alfari and Mindomys hammondi, and provide comparative photographs of the crania and dentition of these species. Finally, we compare morphological characteristics with the newly purposed sistertaxon, Melanomys caliginosus (see Weksler 2006). Reconstruction of phylogenetic relationships is beyond the scope of the current manuscript and will be examined with morphological and molecular analyses in a future manuscript.

\section{Materials and Methods}

Our trapping efforts were undertaken over several years in and around the Monteverde Cloud Forest Reserve (Fig. 1 in McCain 2004), a $10,500 \mathrm{~h}$ private reserve in Alajuela and Puntarenas provinces in northwestern Costa Rica's Cordillera de Tilarán. At 1250-1300 m in the Peñas Blancas Valley, McCain set 130 traps per night for seven consecutive nights during the dry season (2002) and two late wet seasons at different sites (2000, 2001), and for five consecutive nights during the early wet season (2001) for a total of 3380 trap nights. The trap types (and numbers) used were: standard folding Sherman live traps $(3 \times 3.5 \times 9$ in) (73), large folding Sherman live traps $(3 \times 3.75 \times 12$ in $)(40)$, Victor snap traps (10), and pitfalls (7). At 1500-1550 m along the continental divide, McCain set the same array of traps during the early wet, two late wet ( 2 sites), and a dry season for a total effort of 3380 trap nights. The same trapping effort was conducted at $1800-1840 \mathrm{~m}, 1000-1050$ $\mathrm{m}$, and 750-800 m. See McCain (2003, 2004) for additional details of trapping procedures. Timm ran pitfall traps along the continental divide at $1550 \mathrm{~m}$ from $12-$ 22 Oct 2000, with a total of 22 trap nights with small pitfall traps $(6.5 \mathrm{~cm}$ diameter $)$ and 10 trap nights with larger pitfall traps (14 cm diameter). Additionally, Timm has trapped extensively on the Pacific

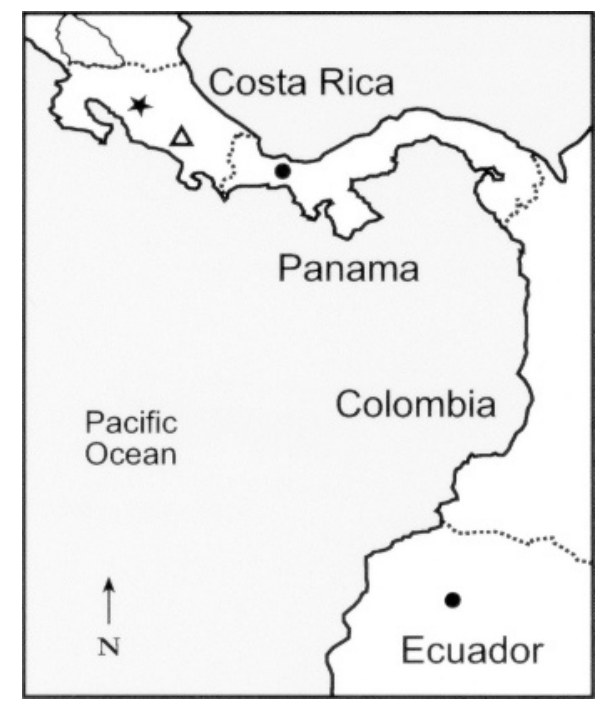

Fig. 1. Verified distribution of Sigmodontomys aphrastus in lower Central America and northern South America based on the seven known specimens. The new specimens reported herein from Monteverde in Costa Rica's Cordillera de Tilarán are represented by the star $(\star)$; the type locality at San Joaquín de Dota in the Cordillera de Talamanca is represented by the triangle $(\triangle)$; the specimens from the Cordillera de Chiriquí of western Panama and from Volcán Pichincha in northwestern Ecuador are both represented by closed circles (•). See Materials and Methods section for details on localities and museum catalog numbers.

slopes of the Monteverde region over the past two decades with both Sherman live traps and pitfalls at elevations ranging from $1100 \mathrm{~m}$ to the continental divide at $1840 \mathrm{~m}$ on Cerro Amigos.

We personally examined six of the seven known specimens of Sigmodontomys aphrastus. Philip Myers provided us with excellent photographs and with measurements of the type specimen (UMMZ 62875), which we were not able to examine personally. External and cranial comparisons were made between specimens of $S$. aphrastus and those of $S$. alfari $(n=29)$, Mindomys hammondi $(n=$ $2)$, Nephelomys albigularis $(n=5)$, and $N$. devius $(n=18)$. Nineteen cranial dimensions were measured using dial calipers 
graduated to $0.01 \mathrm{~mm}$. Three specimens of $S$. aphrastus have damaged skulls, so only eight measurements are used in multivariate analyses (here designated in bold). The majority of cranial measurements used are detailed and illustrated by Musser et al. (1998), which include length of upper molar row (CLIM1-3), width of M1 (BM1), breadth across bony palate at M1-M1 (BBP), length of bony palate (LBP), postpalatal length (PPL), length and breadth of incisive foramen (LIF, BIF), length of upper diastema (LD), breadth of zygomatic plate (BZP), occipitonasal length $(\mathrm{ONL})$, breadth of rostrum (BR), interorbital breadth (IB), zygomatic breadth (ZB), and lambdoidal breadth (LB). Height of braincase (HBC) was measured following Musser (1979); length of rostrum (LR) was measured at an angle from the tip of the nasals to the posterior margin of the zygomatic notch. The breadth of the second and third molars (BM2, BM3) and the breadth across the bony palate across M3-M3 (BBP3) were measured also.

We used principal component analysis (PCA) to assess which cranial characteristics are important in explaining the variation among the specimens and to visually display morphometric differentiation between the species. PCA on the correlation matrices of the eight cranial characters was run using SAS (SAS Inc. 1999-2001). Correlation matrices are used because there is no reason to suspect that higher variability within a variable indicated higher overall importance. We used the latent root criterion for determination of meaningful components of variation in the PCA analyses (McGarigal et al. 2000). This criterion applies to PCAs of correlation matrices and assumes that eigenvalues less than one are not considered important, because they account for less variability on average than in any single original variable.
Specimens from the following institutions were used in this study: American Museum of Natural History, New York (AMNH); Field Museum, Chicago (FMNH); Museo Nacional de Costa Rica, San José (MNCR); Museum of Comparative Zoology, Harvard University, Cambridge (MCZ); National Museum of Natural History, Washington, D.C. (USNM); University of Kansas Natural History Museum, Lawrence (KU); University of Michigan Museum of Zoology, Ann Arbor (UMMZ). One specimen of S. aphrastus obtained at Monteverde (KU 159021) will be deposited in the Museo Nacional de Costa Rica, San José.

\section{Results}

As part of our ongoing research on Central American mammals, two individuals of Sigmodontomys aphrastus, a sigmodontine species previously unknown from northwestern Costa Rica's Cordillera de Tilarán, were captured in the Monteverde Cloud Forest Reserve. Our identification is based on the comparison of external and cranial characters of these two specimens with those of four of the five previously known specimens of $S$. aphrastus, with those shown in photographs and measurements of the holotype, and with those of a variety of other oryzomyines. The only previously known specimen from Costa Rica is the holotype, which was collected in the Cordillera de Talamanca at San Joaquín de Dota, San José Province, in 1931. There are now three specimens of $S$. aphrastus known from Costa Rica, two from Panama, and two from Ecuador (Fig. 1). These seven specimens of this poorly known species range in age from juvenile to old adult with worn teeth; all specimens were taken at middle elevations, and the species is documented from northwestern Costa Rica's Cordillera de Tilarán to Volcán Pichincha on the western slope of the Andes in northern Ecuador. The eleva- 
tional range of these seven specimens is 1220 to $2000-2500 \mathrm{~m}$.

As judged by tooth eruption and wear, the youngest individual (KU 159021) is the juvenile caught in Costa Rica with M3 only partially erupted, and the oldest, with considerable tooth wear, is a specimen from Volcán Pichincha, Ecuador (MCZ 50396). External measurements, based on collectors' notes and tags, and nineteen cranial dimensions for all known specimens of $S$. aphrastus, a representative sample of $S$. alfari, Nephelomys devius, and a single Mindomys hammondi are shown in Table 1.

Comparing S. aphrastus, S. alfari, and $N$. devius, the principal components analysis produced eigenvalues ranging between 2.802 and 0.062 . According to the latent root criterion, only the first three principal components are significant (McGarigal et al. 2000). Eigenvalues and unit eigenvectors for the first three components of variation are presented in Table 2. The first two principal components are a contrast between the breadth of bony palate, the distance between the first and last molars (BBP1, BBP3), and the length of bony palate (LBP) with the length of the tooth row (CLIM1-3), the size of the last molar (BM3), and the contrasting breadth of the zygomatic plate (BZP). The differential morphology of three species can be distinguished clearly in a plot of the first two principal components (Fig. 2).

\section{Redescription of Sigmodontomys aphrastus (Harris, 1932)}

The dorsal pelage is long, thick, and soft. In most specimens, it is smooth and shiny but more woolly and fluffy in the adult female from Ecuador and in the young adult from Panama. Ventral fur is sparser and shorter than the dorsal fur, and is paler gray with pronounced ochraceous highlights. Laterally, most specimens have noticeably more orangish highlights than dorsally. Dorsal-ventral countershading is distinct but not as strong as in many oryzomyines. All hairs, both dorsally and ventrally, have slate gray bases. Most specimens have a rich, dark, and grizzled fur dorsally of deep browns with orange highlights. Some have deeper browns across the rump and head, whereas others have more orangish highlights across the face and shoulders. The young adult from Panama has an overall pale gray pelage with occasional yellowish highlights, but the juvenile from Costa Rica is darker overall than the adults. The adult from Monteverde has white around the mouth and rhinarium, and the old adult male from Volcán Pichincha has many large, conspicuous, white blotches scattered irregularly, both dorsally and ventrally. Pinnae are small (not reaching the eye when laid forward) and sparsely to moderately covered with blackish, dark brown, or reddish-brown hairs both internally and externally. Mystacial and superciliary vibrissae are very long (extend posteriorly beyond caudal margins of pinnae), dark, and numerous. Manual claws are small and unkeeled; several specimens have noticeable deep orange pigmentation at tips. Hind feet are long and robust with sparse to moderate coverage of pale brown to dark brown hairs dorsally and naked ventrally. Feet lack well-developed natatory fringes and interdigital webs. The feet are a pale brown coloration with small, dark squamae visible dorsally. Plantar surface is densely covered with distinct squamae distal to thenar pad (heel is smooth); the hypothenar pad is absent or vestigial (extremely reduced). Interdigital and thenar pads are large and fleshy, with interdigitals 2 and 3 set apart from 1 and 4 as pairs. The second and third interdigital pads are lightly pigmented as compared to the other pads. Digits dI-dIV are long and of nearly equal length, with claw of dI extending just beyond base of phalange 1 of dII and claw of $\mathrm{dV}$ extending beyond middle of phalange 2 of dIV. Sparse tufts 


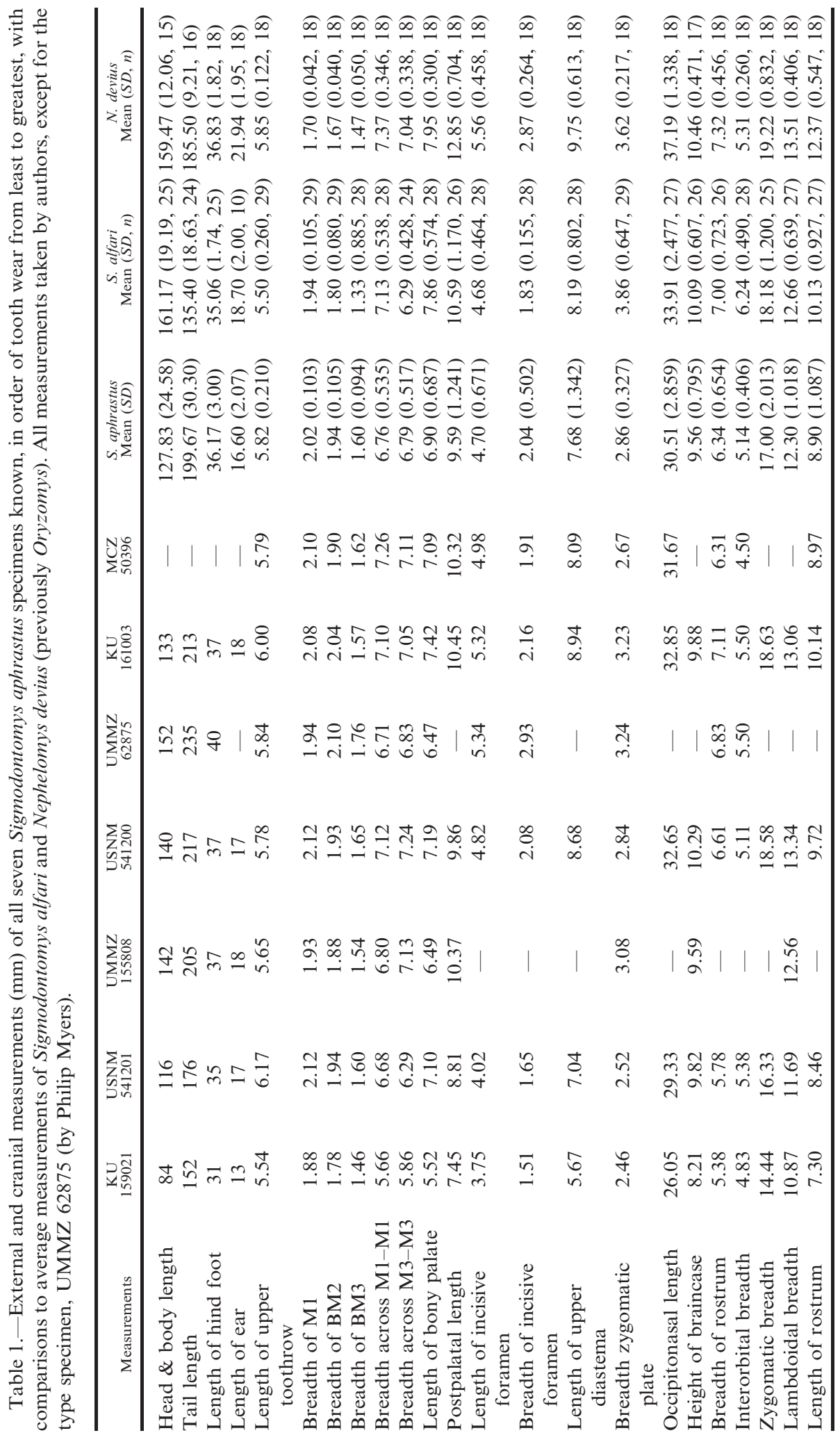


Table 2.-Eigenvectors and eigenvalues for the first three axes of the principal components analysis and canonical coefficients and eigenvalues for the two canonical axes of Sigmodontomys aphrastus, S. alfari, and Nephelomys devius using eight cranial variables (see Materials and Methods for abbreviations).

\begin{tabular}{|c|c|c|c|c|c|}
\hline Measurement & $\mathrm{PC} 1$ & $\mathrm{PC} 2$ & PC3 & CA1 & $\mathrm{CA} 2$ \\
\hline CLIM1-3 & 0.283243 & 0.485201 & 0.002927 & & \\
\hline BM1 & -0.206149 & -0.069189 & 0.660632 & 2.47016 & 0.23220 \\
\hline BM2 & -0.114680 & 0.127876 & 0.686633 & & \\
\hline BM3 & 0.206730 & 0.566823 & 0.154536 & -0.74303 & 1.64358 \\
\hline BBP1 & 0.515285 & -0.185868 & 0.168765 & -0.86774 & 0.09020 \\
\hline BBP3 & 0.498870 & 0.247484 & 0.032380 & & \\
\hline LBP & 0.460968 & -0.279109 & 0.043562 & 0.17556 & -1.19733 \\
\hline $\mathrm{BZP}$ & 0.307419 & -0.498453 & 0.191787 & & \\
\hline Eigenvalue & 2.8017 & 2.2820 & 1.8477 & 6.8494 & 3.4426 \\
\hline
\end{tabular}

of rather short (almost as long as the claw), brown ungual hairs at bases of claws on $\mathrm{dII}-\mathrm{dV}$ may be present or absent. Tail is much longer than head and body $(1.5 \times$ HBL or more) and covered sparsely with short, stout, black or brown hairs with conspicuous hexagonal epidermal scales; reduced terminal tuft of hairs present. The tail is unicolored, uniformly brown, except for patches of slightly paler skin ventrally at base and white tips on the adult and juvenile from Monteverde. Mammary complement consists of eight teats in inguinal, abdominal, postaxial, and pecto-



Fig. 2. Plot of specimen scores on the first two axes of the principal components analysis (PCA) for all known specimens of Sigmodontomys aphrastus $(\bullet), 23$ S. alfari $(\square)$, and 18 Nephelomys devius $(\triangle)$ based on 8 cranial and dental characters. The specimens of $S$. aphrastus are arrayed from left to right mainly by age, as the youngest specimen (KU $159021)$ is on the far left and the adults are grouped on the right. ral pairs. For a summary of external measurements see Table 1 .

Skull has a short, stout rostrum flanked by very shallow zygomatic notches and a slightly inflated braincase with welldeveloped temporal crests (Figs. 3A, B, 4). Lambdoidal and nuchal crests are developed in older adults. Interorbital region is anteriorly convergent with strongly beaded supraorbital margins. Posterior margin of zygomatic plate is anterior to M1 alveolus, and anterior margin is straight, without an anterodorsal spinous process. Zygomatic arches converge anteriorly and are wider at the squamosal root. Jugal present and large with the maxillary and squamosal zygomatic processes widely separated and not overlapping in lateral view. Nasal bones have acutely angled posterior margins that extend posteriorly behind lacrimals. Lacrimals usually have longer maxillary than frontal sutures. Posterior wall of the orbit is smooth. Frontosquamosal suture is anterior to frontoparietal suture (dorsal facet of frontal in broad contact with squamosal). Parietals have broad lateral expansions. The interparietal bone is large, truncated anteriorly, and broadly triangular posteriorly with lateral wings. Basicranial flexion is weakly pronounced and foramen magnum orientation is mostly caudad. Incisive foramina are narrow and short, not extending posteriorly to level of M1 alveoli, widest at 


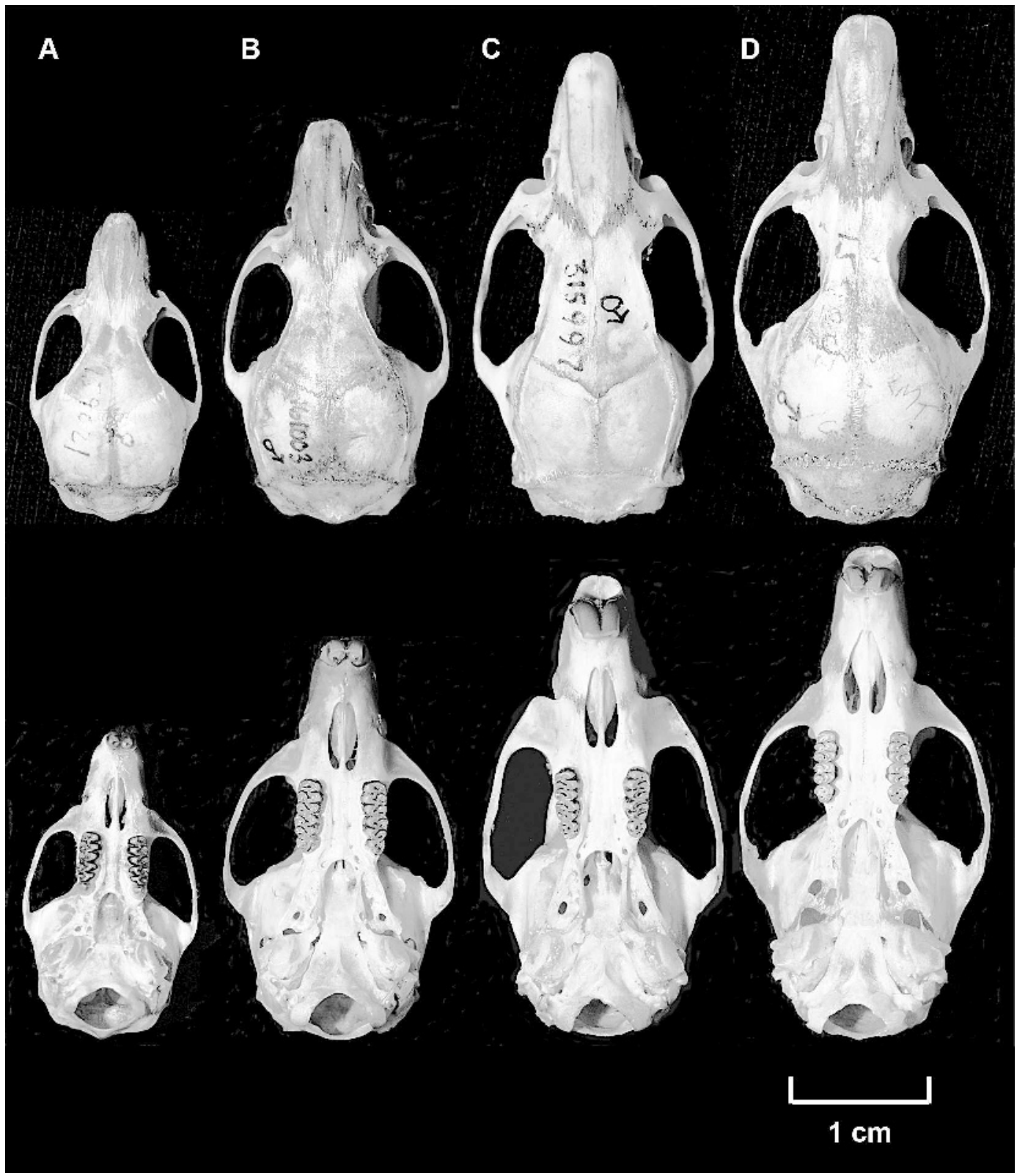

Fig. 3. Dorsal and ventral cranial views (ca. $1.75 \times$ ) of the two new specimens of Sigmodontomys aphrastus from the Monteverde Cloud Forest Reserve, Costa Rica: (a) the juvenile female (KU 159021); (b) the adult male (KU 161003); (c) a specimen of S. alfari from Almirante, Panama (USNM 315997); and (d) a specimen of Nephelomys devius from the Monteverde Cloud Forest Reserve, Costa Rica (KU 159002).

midlength, and taper symmetrically anteriorly and posteriorly. Auditory bullae are of an intermediate size relative to the exposed periotic bone. Bony palate between the molar rows is smooth or weakly sculpted, short, and narrow. Posterolat- eral palatal pits are simple and small, usually unrecessed in fossae. Mesopterygoid fossa penetrates anteriorly between maxillae; bony roof of mesopterygoid fossa is usually perforated by narrow sphenopalatine vacuities (the juvenile 


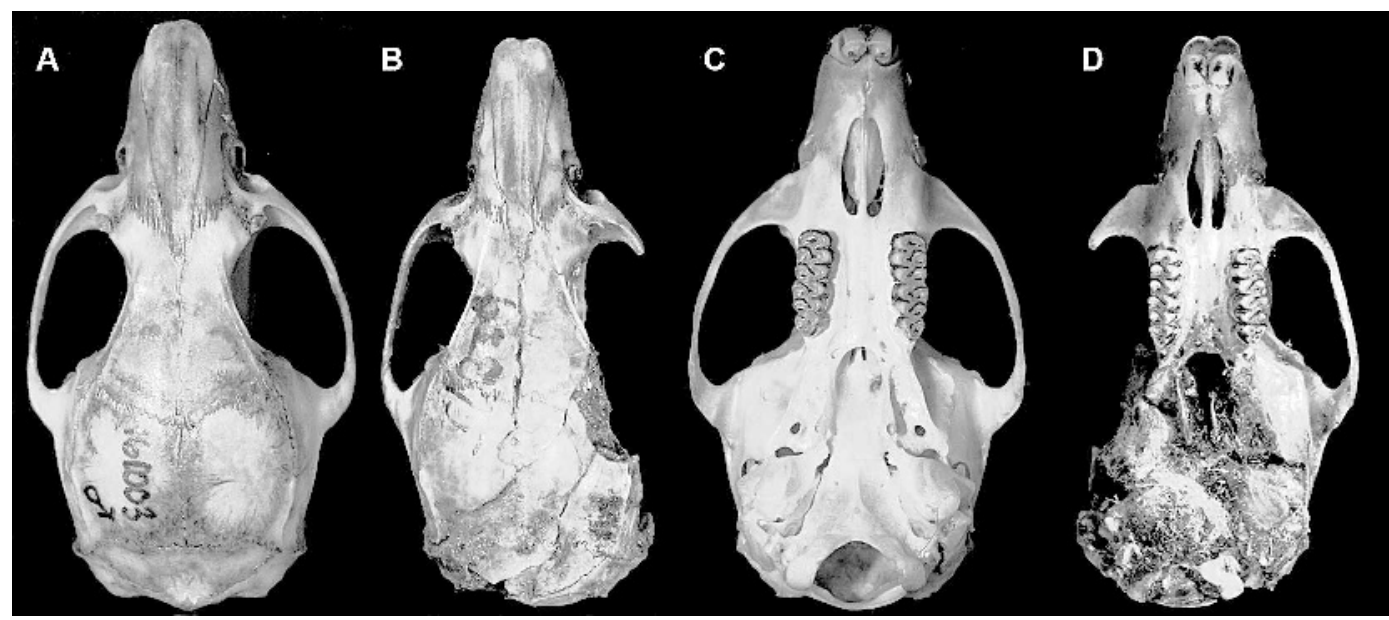

Fig. 4. Dorsal and ventral cranial views (ca. $1.75 \times$ ) of the adult specimen of Sigmodontomys aphrastus from the Monteverde Cloud Forest Reserve, Costa Rica with the holotype from San Joaquín de Dota, Costa Rica: (a) dorsal view of new adult male (KU 161003); (b) dorsal view of adult female holotype (UMMZ 62875); (c) ventral view of new adult male (KU 161003); and (d) ventral view of adult female holotype (UMMZ 62875).

from Monteverde has a completely ossified mesopterygoid roof). Alisphenoid strut is absent (buccinator-masticatory foramen and accessory foramen ovale are confluent), and alisphenoid canal has a large anterior opening. Stapedial foramen and posterior opening of alisphenoid canal is small, squamosal-alisphenoid groove and sphenofrontal foramen are absent, and secondary anastomosis of internal carotid crosses dorsal surface of pterygoid plate (carotid circulatory pattern 3 of Voss 1988). Posterior suspensory process of the squamosal is absent. Postglenoid foramen is large and rounded. Subsquamosal fenestra is vestigial or absent. Periotic is exposed posteromedially between ectotympanic and basioccipital but usually not extending anteriorly to carotid canal. Mastoid is unfenestrated. Capsular process of lower incisor alveolus is absent or reduced. Superior and inferior masseteric ridges are conjoined anteriorly as single crest below $\mathrm{m} 1$. The coronoid processes are long, thin, pointed, and posteriorly angled dorsally, reaching the level of the rounded condyloid processes.
Upper incisors are ungrooved, opisthodont, and covered with orange enamel anteriorly with smoothly rounded enamel bands. Maxillary toothrows are mostly parallel with a slight divergence posteriorly and molars are large, complex, and bunodont (Fig. 5). Labial and lingual flexi of M1 and M2 are deeply interpenetrating; labial flexi are convoluted (wrinkled) and enclosed by a cingulum. First upper molar (M1) anterocone not divided into labial and lingual conules (anteromedian flexus absent). Anteroloph is well developed and fused with the anterostyle on labial cingulum and fused with anterocone (anteroflexus reduced or absent). Protostyle is absent. Mesolophs are present on all upper molars. Paracone is usually connected by an enamel bridge to posterior moiety of protocone, and median mure is connected to the protocone. Second upper molar (M2) protoflexus is absent, mesoflexus present as single internal fossette (a second very small labial fossette is present in the adult from Panama), and paracone has no accessory loph. Third upper molar (M3) has a posteroloph and diminutive hypo- 


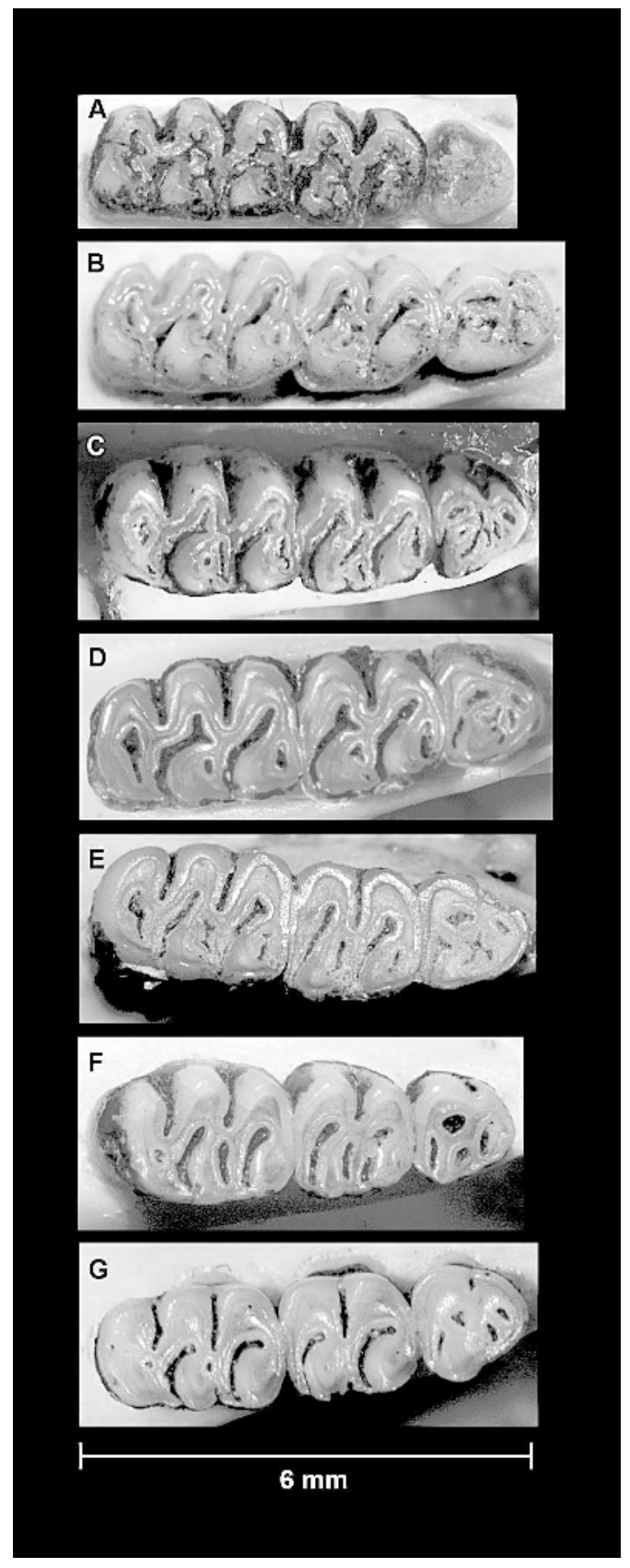

Fig. 5. Molar tooth rows (upper right) of five Sigmodontomys aphrastus: (a) the juvenile female from the Monteverde Cloud Forest Reserve, Costa Rica (KU 159021), (b) the immature male from Chiriquí, Panama (USNM 541201), (c) the holotype-an adult female from San Joaquín de Dota, Costa Rica (UMMZ 62875), (d) the adult male from the Monteverde Cloud Forest Reserve, Costa Rica (KU 161003), and (e) the adult male from Guarumos, Ecuador (MCZ 50396); (f) a specimen of flexus (the latter tending to disappear with moderate to heavy wear). Accessory labial root of M1 is present. First lower molar (m1) anteroconid has no anteromedian flexid (Fig. 6). Both the anterolabial cingulum and a small anterolophid are present on all lower molars (the latter disappear with moderate to heavy wear). Ectolophid is absent on $\mathrm{m} 1$ and $\mathrm{m} 2$. Mesolophid is present and distinct on $\mathrm{m} 1$ and $\mathrm{m} 2$. Posteroflexid present on $\mathrm{m} 3$. Accessory lingual and labial roots are present on $\mathrm{m} 1$. For cranial measurements see Table 1.

Stomach is unilocular-hemiglandular with glandular epithelium extending into corpus. Gall bladder is absent.

\section{Discussion}

Comparisons with other taxa

Sigmodontomys aphrastus was consistently recovered as a member of a clade composed of Melanomys caliginosus and Sigmodontomys alfari in the phylogenetic analyses of Weksler (2006); comparisons with these taxa are provided here. In addition, we compare it with Mindomys hammondi and Nephelomys devius (see Weksler et al. 2006 for new classification of oryzomyines). Although these taxa are not closely related to $S$. aphrastus (Weksler 2003, 2006), they occur at the same localities where $S$. aphrastus was collected, are externally similar to it, and have been considered to be taxonomically close to $S$. aphrastus historically (Hershkovitz 1948, Hall \& Kelson 1959). Table 3 summarizes key morphological comparisons among these taxa.

Sigmodontomys aphrastus differs from S. alfari by its considerably smaller body

$\leftarrow$

S. alfari from Almirante, Panama (USNM 315997); and $(\mathrm{g})$ a specimen of Nephelomys devius from the Monteverde Cloud Forest Reserve, Costa Rica (KU 159002). 


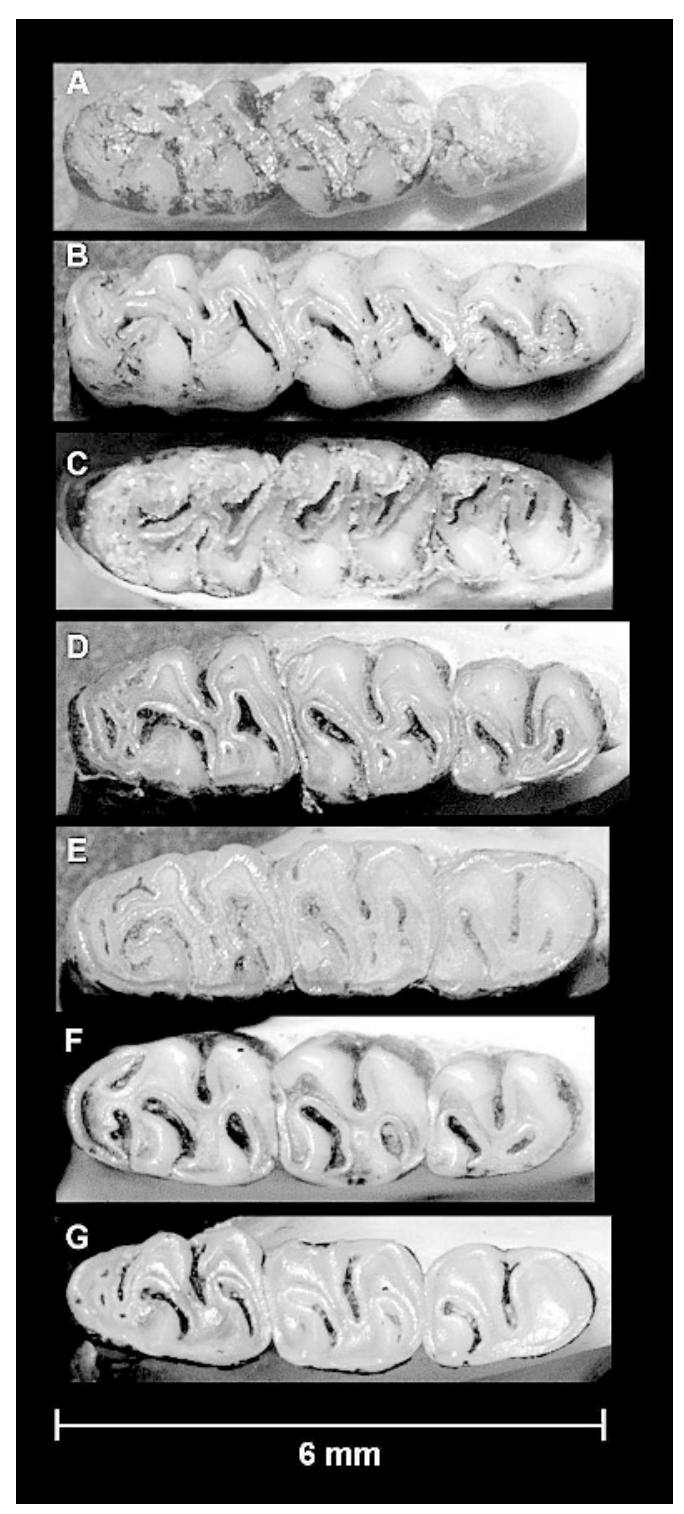

Fig. 6. Molar tooth rows (lower right*) of five Sigmodontomys aphrastus: (a) the juvenile female from the Monteverde Cloud Forest Reserve, Costa Rica (KU 159021), (b) the immature male from Chiriquí, Panama (USNM 541201), (c) the holotype-an adult female from San Joaquín de Dota, Costa Rica (UMMZ 62875; *lower left), (d) the adult male from the Monteverde Cloud Forest Reserve, Costa Rica (KU 161003), and (e) the adult male from Guarumos, Ecuador (MCZ 50396); (f) a specimen of $S$. alfari from Almirante, Panama (USNM 315997); and (g) a specimen of Nephelomys devius from the Monteverde Cloud Forest Reserve, Costa Rica (KU 159002). size (adults average $33.2 \mathrm{~mm}$ smaller) and much longer tail (average $64.3 \mathrm{~mm}$ longer) with a small terminal tuft (Table 1). The tail of $S$. alfari is slightly longer than or subequal to head-and-body length and lacks the terminal tuft. S. aphrastus has much longer vibrissae; in $S$. alfari the vibrissae do not extend posteriorly behind the pinnae as in S. aphrastus. Sigmodontomys aphrastus lacks the interdigital webs on hind feet that are present in S. alfari. The second and third digital pads are lightly pigmented in $S$. aphrastus, whereas they are heavily pigmented in $S$. alfari. The hexagonal tail scales of $S$. aphrastus are smaller, thinner, and not as visible to the naked eye as in S. alfari. Additionally, the pelage of $S$. aphrastus is somewhat longer, softer, and has fewer orangish or yellowish highlights than does that of $S$. alfari. Sigmodontomys aphrastus and $S$. alfari both have large, complex molars with four molar roots in M1 and three in $\mathrm{m} 1$, small auditory bullae, defined postorbital ridge, subsquamosal fenestra, derived carotid arterial circulation, and well-developed supraorbital crests. Sigmodontomys aphrastus has a less robust and a broader skull with a more inflated braincase than does $S$. alfari. The zygomatic arches in $S$. alfari are more squared and with more prominent supraorbital beading and temporal ridges than in $S$. aphrastus. Nasal bones in $S$. aphrastus have acutely angled posterior margins, while nasals of $S$. alfari have blunt posterior margins. The zygomatic plate is broader and forms a deeper notch in $S$. alfari. Sigmodontomys aphrastus has a well developed jugal, which is reduced or absent in $S$. alfari. In $S$. aphrastus the bony palate between the tooth rows is narrower and shorter, extending to the posterior borders of M3s only in the oldest individuals and M3s are only slightly smaller than the M2s; whereas in $S$. alfari the palatal bone extends well beyond the M3s by almost a molar length and the M3s are considerably smaller 





than the M2s. Sigmodontomys alfari also has more complex palatal pit morphology than does $S$. aphrastus. Additionally, the capsular processes are considerably smaller in $S$. aphrastus; they form broad shelves in S. alfari. Sigmodontomys aphrastus has more lophodont upper molars (the labial and lingual flexi do not interpenetrate deeply on the upper molars of $S$. alfari) and has an anterolabial cingulum on $\mathrm{m} 2$ that is absent in $S$. alfari.

Sigmodontomys aphrastus differs from Melanomys caliginosus by its larger body size (adults average $6.3 \mathrm{~mm}$ larger) and much longer tail (average $65.7 \mathrm{~mm}$ longer) with small terminal tuft (lengths of Melanomys from Reid 1997). The tail of Melanomys is shorter than the length of head and body, and lacks a terminal tuft. They have distinctly different fur coloration: S. aphrastus has brownish pelage with orange highlights, whereas the fur in Melanomys is uniformly dark, almost black. Sigmodontomys aphrastus has much longer vibrissae; the vibrissae do not extend posteriorly behind the pinnae in Melanomys. Melanomys has a distinct hypothenar pad on the hind foot, which is absent or vestigial in $S$. aphrastus. The nasal bones of $S$. aphrastus have acutely angled posterior margins, whereas Melanomys has blunt posterior margins. In Melanomys, the zygomatic plate is broader and forms a deeper notch. Sigmodontomys aphrastus has a developed jugal, which is reduced or absent in Melanomys. Sigmodontomys aphrastus also has more lophodont upper molars (the labial and lingual flexi do not interpenetrate deeply on the upper molars of Melanomys). The paracone and protocone are connected by median moiety in Melanomys but have a posterior connection in S. aphrastus.

Sigmodontomys aphrastus differs from Mindomys hammondi by its smaller body size (the full-grown adult male $S$. aphrastus from Monteverde is about the same size of a young $M$. hammondi) and has a proportionally longer tail with small terminal tuft. The tail of Mindomys is slightly longer than the head and body length, lacks terminal tuft, and has rectangular scales, not hexagonal ones as in S. aphrastus. Mindomys has shorter and woollier fur with paler brown coloration with a faint orange tint across the spine and less ochraceous highlights laterally than $S$. aphrastus. Mindomys has a distinct hypothenar pad on the hind foot, which is absent or vestigial in $S$. aphrastus. Sigmodontomys aphrastus has distinct plantar squamae, whereas the sole of the hind foot is sparsely covered with indistinct squamae in Mindomys. The cranium of $M$. hammondi is considerably larger and more robust, with similarly proportioned molars and palatal bones as compared to $S$. aphrastus. The braincase is smooth, more inflated, and has less of an interorbital constriction than does $S$. aphrastus. The nasal bones of $S$. aphrastus have acutely angled posterior margins, whereas Mindomys has blunt posterior margins. Convex-shaped incisive foramina occur in $S$. aphrastus, whereas the incisive foramina are tear-drop shaped in Mindomys. Sigmodontomys aphrastus has the derived carotid circulation pattern, and Mindomys has the stapedial and sphenofrontal foramina and the squamosal-alisphenoid groove. Sigmodontomys aphrastus retains accessory roots on M1/ $\mathrm{m} 1$, which are normally absent on these teeth in Mindomys and has two internal fossettes at the mesoloph of M2 (only one fossette is present on the M2 of Mindomys). Mindomys has a developed hypoflexus on the M3, which is reduced in $S$. aphrastus, and an ectolophid on $\mathrm{m} 1$, which is absent in $S$. aphrastus.

Sigmodontomys aphrastus externally resembles in dorsal fur coloration, general size, and facial features species of Nephelomys, such as $N$. albigularis and $N$. devius, common rodents in mid and high elevations in the Andean and lower Central American cordilleras. However, S. aph- 
rastus differs from Nephelomys in several traits, the following are the most noteworthy. Sigmodontomys aphrastus has a much longer unicolored tail with small terminal tuft, whereas the tail of Nephelomys is bicolored, slightly longer than head-and-body length, and lacks a terminal tuft. Sigmodontomys aphrastus has longer fur that is occasionally more lax than in Nephelomys, smaller ears, and much longer superciliary vibrissae (the vibrissae do not extend posteriorly behind the pinnae in Nephelomys). Nephelomys retains a distinct hypothenar pad on the hind foot, which is absent or vestigial in S. aphrastus. Sigmodontomys aphrastus has much wider hind feet and distinct plantar squamae, whereas the sole of the hind foot is entirely smooth in Nephelomys. Only sparse tufts of short ungual hairs are present on pedal digits II-V of $S$. aphrastus but are denser and longer in Nephelomys. In comparison with $S$. aphrastus, $N$. albigularis and $N$. devius have a much longer, narrower skull with an elongated rostrum, greater constriction at the interorbitals, a larger interparietal, distinctly smaller and less complex, rectangular molars. Nasal bones of $S$. aphrastus have acutely angled posterior margins, whereas Nephelomys has rounded or squared posterior margins. Interorbital regions are cuneate with beaded margins in $S$. aphrastus, but the interorbital region is hourglass-shaped with smooth supraorbital margins in Nephelomys. Sigmodontomys aphrastus has a shallower zygomatic notch, whereas the zygomatic plate is broader and forms a deeper notch in Nephelomys. Sigmodontomys aphrastus retains a developed jugal, which is reduced or absent in Nephelomys, and displays a derived carotid circulation pattern absent in $\mathrm{Ne}$ phelomys. The subsquamosal fenestra is always present and developed in Nephelomys but absent or extremely reduced in S. aphrastus. Sigmodontomys aphrastus retains accessory roots on M1 (normally absent in Nephelomys) but lacks the M1 anteromedian flexus and the ectolophid on $\mathrm{m} 1$ (both present in Nephelomys). Of the cranial measurements taken, all measurements are larger for $N$. devius than for $S$. aphrastus, except breadth of the molars (Table 1).

Taxonomic comments. - Cadena et al. (1998:11) assigned a recently collected specimen (ICN 13663) to the genus Sigmodontomys, stating it "...probably represents an undescribed species of the genus." The specimen was collected in cloud forest at $1300 \mathrm{~m}$ in the Colombian Chocó of western Nariño Department. They characterized the single adult male as having an extremely long tail; glossy, buffy, brown dorsal pelage; long, prominent vibrissae; cuneate interorbital with weakly developed supraorbital ridges; and oval (rather than rectangular) molars. Although these traits are shared by Sigmodontomys aphrastus, the undescribed species has traits that are clearly at odds with the two currently recognized species of Sigmodontomys: narrow hind feet, short palate without posterolateral palatal pits, and a well-developed alisphenoid strut. In fact, the latter two characters are in contrast with 2 putative oryzomyine synapomrophies (Voss and Carleton 1993): absence of alisphenoid and presence of long palate with prominent posterolateral palatal pits. Although some oryzomyines possess one or the other trait, there is no oryzomyine with both alisphenoid strut and short palate (Weksler 2006). Both states are commonly observed among thomasomyine rodents (Pacheco 2003). Further examination of this Chocó exemplar is necessary for its taxonomic clarification.

The phylogenetic relationships between Sigmodontomys aphrastus, S. alfari, and Melanomys varied among the analytic permutations of Weksler (2006). Sigmodontomys aphrastus was recovered as sister species to $S$. alfari in the analysis of morphology-only matrix when coding 
polymorphic character-states as intermediate steps between fixed character-states (Weksler 2006, Fig. 35). In the total evidence analysis of morphological and molecular data, Melanomys caliginosus and $S$. aphrastus are recovered as sister species, although molecular data was not included for S. aphrastus. Additional data are necessary for the resolution of this unresolved area of oryzomyine phylogeny, particularly the inclusion of molecular data for $S$. aphrastus which are now available from the adult specimen recently collected at Monteverde (Weksler et al. in prep.).

\section{Ecology of Sigmodontomys aphrastus}

Habitat.-Both specimens from Monteverde were taken in ground sets. The juvenile female was captured along the continental divide at $1550 \mathrm{~m}$ and the adult male was captured at $1250 \mathrm{~m}$ on the Caribbean slope of Cordillera de Tilarán in northwestern Costa Rica in 2000 and 2002, respectively. Both specimens were taken in intact, mature forests that are classified as lower montane rain forest and premontane rain forest, respectively (Haber 2000). The lower montane rain forest along the continental divide at $1550 \mathrm{~m}$ is dominated by cloud forest vegetation with a variable and broken canopy at about 5$15 \mathrm{~m}$ with pronounced epiphyte and moss growth and a moderately dense ground cover of mosses, ferns, herbs, and shrubby vegetation. This forest experiences substantial rainfall during the wet season (May-December) and heavy misting for most of the year. The forest along the continental divide where the juvenile female was captured is within a few meters of the elfin forest (3-5 m canopy) on an exposed ridge molded by the high winds and driven precipitation coming from the Caribbean.

A lush evergreen forest characterizes premontane rain forest vegetation (700$1400 \mathrm{~m}$ at Monteverde), where canopy height and continuity decrease with ele- vation, and epiphyte and moss loads increase with elevation. The forest where the adult male was caught had a tall, somewhat broken canopy (15-30 m) with heavy epiphyte and moss growth. There was a multi-layered understory of ferns, shrubs, herbs, young trees, and monocots. Rainfall is still considerable during the rainy season, although the year-round dense mists and wind-driven rain are not as pervasive as at the continental divide. The habitat directly around the trap where the adult male was captured was a large, decomposing ( $\sim 1 \mathrm{~m}$ diameter $)$ fallen tree trunk with several young trees growing out of it. Overhead the canopy was closed and the ground cover was sparse with occasional plants but a deep litter layer around the trap. Within a few meters was very dense ground cover of low vegetation. For a broad overview of the plant communities in the vegetation zones at Monteverde, see Haber (2000), and for more detailed climatic data see Clark et al. (2000).

The holotype was caught at San Joaquín de Dota, Costa Rica, in undisturbed premontane rain forest on the Pacific slope of the Cordillera de Talamanca at $1220 \mathrm{~m}$. Both Ecuadorian specimens were from apparently undisturbed forest on the Pacific slope of Volcán Pichincha, the first from upper montane rain forest between 2000-2500 $\mathrm{m}$ near Guarumos, and the second from lower montane rain forest near Mindo (Voss 1988). The two Panamanian specimens were trapped in disturbed, fairly open, relatively dry habitat, which included mixed grass, weeds, brush, oaks, and other trees (R. H. Pine, pers. comm.). No $S$. aphrastus have been captured in disturbed habitats in Monteverde, despite Timm's extensive trapping efforts in a wide variety of disturbed habitats within and near the community over two decades, and the species has not been detected anywhere along the Pacific slopes of the Monteverde region where 
we have trapped extensively. All known specimens of $S$. aphrastus, except the two specimens from Panama, were taken in intact forest.

Community composition.-Along the continental divide at $1500-1550 \mathrm{~m}$ where the juvenile female $S$. aphrastus was trapped, we also obtained the following terrestrial or scansorial species: Cryptotis nigrescens, Heteromys nubicolens, Nephelomys devius, Nyctomys sumichrasti, Peromyscus nudipes, Reithrodontomys gracilis, Reithrodontomys sp., and Scotinomys teguina. Peromyscus nudipes dominated numerically $(51 \%$ of individuals captured), followed by Heteromys nubicolens (24\%), Scotinomys teguina (15\%), and Nephelomys devius (9\%); all other species were relatively rare. At $1250-1300 \mathrm{~m}$ on the Caribbean slope where the adult male was obtained, we captured Marmosa mexicana, Cryptotis nigrescens, Heteromys nubicolens, Nephelomys devius, Nyctomys sumichrasti, Peromyscus nudipes, Reithrodontomys gracilis, and Scotinomys teguina. Again, Peromyscus nudipes dominated numerically $(50 \%$ of individuals captured), followed by Heteromys nubicolens (21\%), Nephelomys devius (17\%), and Scotinomys teguina (10\%); all other species were relatively rare. Two Heteromys nubicolens were caught in the same trap (baited with cracked corn, mixed seeds, and vanilla) as the adult male $S$. aphrastus over the seven days the trap was out. For additional information on other mammals that occur in the Reserve and general ecology of species in this area see Timm \& LaVal (2000) and McCain (2003, 2004, 2006).

At San Joaquín de Dota, Costa Rica, the following species are known to occur, based on specimens in the University of Michigan collection obtained by Austin Smith when he acquired the holotype of S. aphrastus-Marmosa mexicana, Microsciurus alfari, Sciurus granatensis, Oligoryzomys vegetus, Peromyscus nudipes, Reithrodontomys mexicanus, and Tylomys watsoni (Goodwin 1946, McPherson 1985, Carleton \& Musser 1995). In Panama, R. H. Pine and R. J. Izor obtained the following species of terrestrial mammals in the vicinity of where they captured the two specimens of $S$. aphrastus in 1980: Marmosa robinsoni, Oligoryzomys fulvescens, Peromyscus nudipes, Reithrodontomys mexicanus, and Sigmodon hirsutus (R. H. Pine, pers. comm.). And in Ecuador at Mindo, R. S. Voss collected or observed Chironectes minimus, Didelphis sp., Marmosa sp., and the rodents, Mindomys hammondi, Handleyomys alfaroi, and Nephelomys moerex along with his one specimen of $S$. aphrastus (Voss 1988).

To date, no specimens of $S$. aphrastus and $S$. alfari have both been taken from the same locality or similar elevations; the two species appear to be elevationally separated, with $S$. aphrastus occurring above $1200 \mathrm{~m}$, and $S$. alfari occurring at and/or below $900 \mathrm{~m}$ (Reid 1997, Musser et al. 1998).

Natural history.-Of the seven known specimens of Sigmodontomys aphrastus, three are females and four are males. All were adults, except for the juvenile female caught by the authors in Monteverde and a young adult male from Panama. The adult male caught at Monteverde had descended testes measuring $7 \times 5 \mathrm{~mm}$, and the adult male from Panama had testes measuring $5 \mathrm{~mm}$ in length. Mammary morphology consists of eight teats in inguinal, abdominal, postaxial, and pectoral pairs; other reproductive specifics remain unknown. We collected one species of tick (Ixodes sinaloa - 2 nymphs, 5 larvae) from the adult male $S$. aphrastus from Monteverde; these are the first parasites reported for this species. Muscle tissue and all major organs of the adult male were preserved in ethanol for future study. The juvenile was captured in a pitfall trap (14 cm diameter) and the adult male was taken in a standard Sherman live trap on the ground. Arrays of 
traps at these sites and at other Caribbean slope sites between $750-1840 \mathrm{~m}$ were placed both on the ground and in the trees (1-3 $\mathrm{m}$ above ground; McCain 2004). To date, no S. aphrastus have been caught arboreally. In McCain's (2004) trapping efforts, half of the Sherman live traps were baited with peanut butter and oats, and the other half were baited with a mixture of grain sorghum, millet, sunflower seeds, and vanilla extract. The adult male $S$. aphrastus was caught in a Sherman with the later bait type. Victor traps were baited with peanut butter and oats. Pitfall traps were not baited by McCain or Timm. The stomach and stomach contents were preserved, but no diet analysis was performed. Given our extensive trapping efforts using various sizes and types of traps in the Monteverde area over the last 20+ years, it is surprising that only two $S$. aphrastus have been detected. Judging from our trapping efforts, as well as those of others, $S$. aphrastus occurs only on the Caribbean slopes there and either occurs in very low densities or is reluctant to enter traps. It is plausible that the detection of so few individuals in the Cordillera de Tilarán may be the result of limited trapping efforts between $1100-1500 \mathrm{~m}$ on the Caribbean slopes. Before the concerted trapping effort of McCain (2003, 2004, 2006) from $850-1840 \mathrm{~m}$, minimal trapping was conducted there, mostly around shelters at 840 and $950 \mathrm{~m}$.

The Monteverde Cloud Forest Reserve is a region of considerable endemism and also the northernmost locality known for Cryptotis nigrescens, Nephelomys devius, and Reithrodontomys creper (Timm \& LaVal 2000) and the southernmost locality for a new species of Heteromys $(H$. nubicolens Anderson \& Timm 2006) as well as for the shrew Cryptotis merriami (Woodman 2000). Sigmodontomys aphrastus is classified as species with "reduced populations" by Costa Rica's Ministerio del Ambiente y Energía
(MINAE 1999, Rodríguez-Herrera et al. 2002). Clearly, additional fieldwork is necessary to document the distribution, population size, and general ecology of $S$. aphrastus in Monteverde and throughout its currently known range at mid-elevations in Central and South America.

\section{Acknowledgments}

The Monteverde Cloud Forest Reserve and the Monteverde Conservation League graciously allowed us to conduct this research in their reserves. Javier Guevara Sequeira and SINAC-Ministerio del Ambiente y Energía provided permits for our research. At Monteverde, Arturo Cruz, Rafael Bolaños, and Richard and Meg LaVal greatly assisted our efforts. In San José, José Mora (Universidad de Costa Rica) and Bernal Rodríguez-H. (MNCR) provided us full access to the collections and curated the specimens we deposited with their respective institutions. We thank Robert P. Anderson, Ronald H. Pine, and Robert S. Voss for unselfishly providing us additional information on specimens they collected. Robert Voss and Robert Anderson provided assistance and accessibility to specimens at the AMNH, and Judith M. Chupasko and Mark Omura were generous and helpful at MCZ. At the USNM, Linda Gordon, Helen Kafka, and Neal Woodman made specimens available to us for study and our work there most productive. Philip Myers provided photographs and measurements of the holotype of $S$. aphrastus, as well as information on other species of mammals in the UMMZ collection. Bernardo Broitman kindly helped revise the Spanish resumen. Robert Anderson, Mike Carleton, Thor Holmes, Ron Pine, Norm Slade, and an anonymous reviewer provided us with detailed and helpful reviews of the manuscript. Heather York provided the skull photographs (except holotype) used in Figures 3-6. The research was supported in part by the $E$. 
Raymond and Mary Hall Fund of the KU Natural History Museum to CMM and RMT, EPSCoR Alaska to MW, and the Madison A. \& Lila Self Graduate Fellowship to CMM.

\section{Literature Cited}

Allen, J. A. 1897. Additional notes on Costa Rican mammals, with descriptions of new species.Bulletin of the American Museum of Natural History 9:31-45.

Anderson, R. P., \& R. M. Timm. 2006. A new montane species of spiny pocket mouse (Rodentia: Heteromyidae: Heteromys) from northwestern Costa Rica.-American Museum Novitates 3509:1-38.

Cadena, A., R. P. Anderson, \& P. Rivas-Pava. 1998. Colombian mammals from the Chocoan slopes of Nariño.-Occasional Papers, Museum of Texas Tech University 180:1-15.

Carleton, M. D., \& G. G. Musser. 1995. Systematic studies of oryzomyine rodents (Muridae: Sigmodontinae): Definition and distribution of Oligoryzomys vegetus (Bangs, 1902).Proceedings of the Biological Society of Washington 108:338-369.

Clark, K. L., R. O. Lawton, \& P. R. Butler. 2000. The physical environment. Pp. 15-38, in N. M. Nadkarni and N. T. Wheelwright, eds., Monteverde: Ecology and conservation of a tropical cloud forest. Oxford University Press, New York, 573 pp.

Goodwin, G. G. 1946. Mammals of Costa Rica.Bulletin of the American Museum of Natural History 87:271-473.

Haber, W. A. 2000. Plants and vegetation. Pp. 39-94, in N. M. Nadkarni and N. T. Wheelwright, eds., Monteverde: Ecology and conservation of a tropical cloud forest. Oxford University Press, New York, 573 pp.

Hall, E. R. 1981. The mammals of North America, vol. 2, 2nd edition. John Wiley \& Sons, New York, 2:601-1181 + 90 .

, \& K. R. Kelson. 1959. The mammals of North America, vol. 2. The Ronald Press Company, New York, 2:547-1083 + 79.

Harris, W. P., Jr. 1932. Four new mammals from Costa Rica.- Occasional Papers of the Museum of Zoology, University of Michigan 248:1-6.

Hershkovitz, P. 1944. A systematic review of the Neotropical water rats of the genus Nectomys (Cricetinae).-Miscellaneous Publications, Museum of Zoology, University of Michigan 58:1-101.

1948. Mammals of northern Colombia. Preliminary report no. 3: Water rats (genus
Nectomys), with supplemental notes on related forms.-Proceedings of the United States National Museum 98:49-56.

IGM. 1972. Indice toponimico de la República del Ecuador. Tomo V (G-H-I-J-K). Instituto Geográfico Militar, Quito, 739-933 pp.

McCain, C. M. 2003. Ecological gradients in diversity and abundance: A search for patterns and processes in small mammal communities. Ph.D. dissertation, University of Kansas, 167 pp.

. 2004. The mid-domain effect applied to elevational gradients: species richness of small mammals in Costa Rica.-Journal of Biogeography 31:19-31.

. 2006. Do elevational range size, abundance, and body size patterns mirror those documented for geographic ranges? A case study using Costa Rican rodents.-Evolutionary Ecology Research 8:435-454.

McGarigal, K., S. Cushman, \& S. Stafford. 2000. Multivariate statistics for wildlife and ecology research. Springer, New York, 283 pp.

McPherson, A. B. 1985. A biogeographical analysis of factors influencing the distribution of Costa Rican rodents.-Brenesia 23:97-273.

Méndez, E. 1993. Los roedores de Panamá. Privately published by author, $372 \mathrm{pp}$.

MINAE (Ministerio de Ambiente y Energía). 1999. Lista oficial de la República de Costa Rica: lista de especies de fauna silvestre con poblaciones reducidas y en peligro de extinción para Costa Rica. in Lista de fauna de importancia para la conservación en Centroamérica y México: listas rojas, listas oficiales y especies en apéndices CITES: 125 140. San José, Costa Rica: World Wildlife Fund, Unión Internacional para la Conservación de la Naturaleza y de los Recursos Naturales (UICN), and Sistema de la Integración Centroamericana.

Musser, G. G. 1979. The species of Chiropodomys, arboreal mice of Indochina and the Malay Archipelago.-Bulletin of the American Museum of Natural History 162:377-445. , \& M. D. Carleton. 1993. Family Muridae. Pp. 501-755, in D. E. Wilson and D. M Reeder, eds., Mammal species of the world: A taxonomic and geographic reference, 2nd edition. Smithsonian Institution Press, Washington, D.C., 1206 pp. , \& . 2005. Superfamily Muroidea. Pp. 894-1531, in D. E. Wilson and D. M. Reeder, eds., Mammal species of the world: A taxonomic and geographic reference, 3rd edition. Johns Hopkins University Press, Baltimore.

, $\longrightarrow$, E. M. Brothers, \& A. L. Gardner. 1998. Systematic studies of oryzomyine rodents (Muridae, Sigmodontinae): Diagnoses 
and distributions of species formerly assigned to Oryzomys "capito".-Bulletin of the American Museum of Natural History 236:1-376.

, \& M. M. Williams. 1985. Systematics studies of oryzomyine rodents (Muridae): Definitions of Oryzomys villosus and Oryzomys talamancae.-American Museum Novitates 2810:1-22.

Pacheco, V. 2003. Phylogenetic analyses of the Thomasomyini (Muroidea: Sigmodontinae) based on morphological data. Ph.D. dissertation, The City University of New York, New York,

Paynter, R. A., Jr. 1993. Ornithological gazetteer of Ecuador, 2nd edition. Museum of Comparative Zoology, Harvard University, Cambridge, Massachusetts, 247 pp.

, \& M. A. Traylor, Jr. 1977. Ornithological gazetteer of Ecuador. Museum of Comparative Zoology, Harvard University, Cambridge, Massachusetts, 152 pp.

Ray, C. E. 1962. Oryzomyine rodents of the Antillean subregion. Ph.D. dissertation, Harvard University, $356 \mathrm{pp}$.

Reid, F. A. 1997. A field guide to the mammals of Central America \& southeast Mexico. Oxford University Press, New York, 334 pp.

Rodríguez-Herrera, B., F. A. Chinchilla, \& L. J. May-Collado. 2002. Lista de especies, endemismo y conservación de los mamíferos de Costa Rica.-Revista Mexicana de Mastozoología 6:19-41.

SAS Inc. 1999-2001. SAS software release 8.2. SAS Institute, Inc., Cary, North Carolina.

Timm, R. M., \& R. K. LaVal. 2000. Mammals. Pp. 223-244, 553-560, in N. M. Nadkarni and N. T. Wheelwright, eds., Monteverde: Ecology and conservation of a tropical cloud forest. Oxford University Press, New York, 573 pp.

Voss, R. S. 1988. Systematics and ecology of ichthyomyine rodents (Muroidea): Patterns of morphological evolution in a small adaptive radiation.-Bulletin of the American Museum of Natural History 188:259-493.

, \& M. D. Carleton. 1993. A new genus for Hesperomys molitor Winge and Holochilus magnus Hershkovitz (Mammalia, Muridae) with an analysis of its phylogenetic relationships.-American Museum Novitates 3085: $1-39$.

Weksler, M. 2003. Phylogeny of Neotropical oryzomyine rodents (Muridae: Sigmodontinae) based on the nuclear IRBP exon.Molecular Phylogenetics and Evolution 29: 331-349.

2006. Phylogenetic relationships of oryzomyine rodents (Muridae: Sigmodontinae): separate and combined analyses of morpho- logical and molecular data.-Bulletin of the American Museum of Natural History 296: 1-149.

, A. R. Percequillo, \& R. S. Voss. 2006. Ten new genera of oryzomyine rodents (Cricetidae: Sigmodontinae).-American Museum Novitates 3537:1-29.

Woodman, N. 2000. Cryptotis merriami Choate in Costa Rica: Syntopy with Cryptotis nigrescens (Allen) and possible character displacement (Mammalia: Insectivora).-Caribbean Journal of Science 36:289-299.

\section{Associate Editor: Gary R. Graves}

\section{Appendix 1}

\section{Specimens Examined}

Locality information not provided by the collector appears in brackets. Where original elevation was reported in feet, we either provide that datum or the metric equivalent to the nearest 10 meters. Those specimens used in multivariate analyses are denoted with an asterisk $(*)$.

Mindomys hammondi (2).-ECUADOR: Napo; Concepción $\left[00^{\circ} 48^{\prime} \mathrm{S}, 77^{\circ} 25^{\prime} \mathrm{W}\right]$ (1, MCZ 52543) [The locality for this specimen may be in error. Concepción is at ca. $300-500 \mathrm{~m}$ in the eastern lowlands (see Paynter 1993), whereas all other known specimens of $M$. hammondi are from the Mindo area of the western slopes of Volcán Pichincha. Paynter (1993) reports that the Olallas collected at Concepción on 25-26; the date on the single specimen of $M$. hammondi obtained by the Olallas is 27 July 1929]. Pichincha; Mindo, $4200 \mathrm{ft} \quad[1,380 \mathrm{~m}] \quad\left[00^{\circ} 03^{\prime} \mathrm{S}\right.$, 78 46’W] (10’, UMMZ 155827) (Voss 1988).

Nephelomys albigularis (5).-PERU: Amazonas: Goncha, 8,500 ft [2790 m] (1क, KU 79328). VENEZUELA: Aragua; Rancho Grande, $1100 \mathrm{~m}$ $\left[10^{\circ} 22^{\prime} \mathrm{N}, 67^{\circ} 41^{\prime} \mathrm{W}\right]$ (Voss 1988) (30॰0', 1\%, KU 120296, 120297, 120298, 120299).

Nephelomys devius (36). - COSTA RICA: Alajuela; Monteverde, Monteverde Cloud Forest Reserve, Cerro Amigos, $1750-1840 \mathrm{~m} \quad\left[10^{\circ} 19^{\prime} \mathrm{N}\right.$, $\left.84^{\circ} 48^{\prime} \mathrm{W}\right]$ (50’0', 2oㅇ, KU 159043, 159044, 160221, 160222, 160982, 160983, 160984); Monteverde, Monteverde Cloud Forest Reserve, Peñas Blancas Trail to Refugio Aleman, $1000-1050 \mathrm{~m}\left[10^{\circ} 18^{\prime} \mathrm{N}\right.$, $\left.84^{\circ} 47^{\prime} \mathrm{W}\right]$ (10’, KU 160985); Monteverde, Monteverde Cloud Forest Reserve, Sendero Pantanosa, $1580 \mathrm{~m}\left[10^{\circ} 18^{\prime} \mathrm{N}, 84^{\circ} 48^{\prime} \mathrm{W}\right]\left(10^{\prime}, \mathrm{KU} 143401\right)$; Monteverde, Monteverde Cloud Forest Reserve, Sendero Peñas Blancas, $1250-1300 \mathrm{~m}\left[10^{\circ} 18^{\prime} \mathrm{N}\right.$, $\left.84^{\circ} 47^{\prime} \mathrm{W}\right]$ (50’0', 2o우, KU 159045, 159046, 159047, 159048, 159050, 159051, 159052). Cartago; Cordil- 
lera de Talamanca, upper Río Macho watershed, Villa Mills, ca $2750 \mathrm{~m}\left[9^{\circ} 33^{\prime} \mathrm{N}, 83^{\circ} 43^{\prime} \mathrm{W}\right]\left(10^{\prime}\right.$, KU 143311); Refugio Nacional de Fauna Silvestre Tapantí, near Río Dos Amigos (19, KU 142137*); San Vito, Coto Brus, Estación Biológica Las Alturas, $1500 \mathrm{~m} \quad\left[8^{\circ} 57^{\prime} \mathrm{N}, \quad 82^{\circ} 50^{\prime} \mathrm{W}\right] \quad(1$,, $\mathrm{KU}$ 158634). Puntarenas; Monteverde, Cfemalebell's Woods, $1500 \mathrm{~m}\left[10^{\circ} 18^{\prime} \mathrm{N}, 84^{\circ} 48^{\prime} \mathrm{W}\right]$ (1ㅇ, KU 143655*); Monteverde, Cerro Amigos, $1,760 \mathrm{~m}$ $\left[10^{\circ} 19^{\prime} \mathrm{N}, 84^{\circ} 48^{\prime} \mathrm{W}\right]\left(30^{\prime}, \mathrm{KU} 142060^{*}, 142061^{*}\right.$, 142062*); Monteverde, Monteverde Cloud Forest Reserve, $1580 \mathrm{~m} \quad\left[10^{\circ} 18^{\prime} \mathrm{N}, 84^{\circ} 48^{\prime} \mathrm{W}\right]$ (1ㅇ, KU 143403*); Monteverde, Monteverde Cloud Forest Reserve, Brillante Trail, 1500-1560 m [10 $18^{\prime} \mathrm{N}$, $\left.84^{\circ} 48^{\prime} \mathrm{W}\right]$ (30׳0”, 1o, KU 160956*, 160958*, 160959*, 160960*); Monteverde, Monteverde Cloud Forest Reserve, Cerro Amigos, 1800-1820 m [10 $\left.19^{\prime} \mathrm{N}, 84^{\circ} 48^{\prime} \mathrm{W}\right]$ (10’, KU 160961*); Monteverde, Monteverde Cloud Forest Reserve, Investigators' Trail, $1550 \mathrm{~m}\left[10^{\circ} 18^{\prime} \mathrm{N}, \quad 84^{\circ} 48^{\prime} \mathrm{W}\right] \quad\left(40^{\prime} \mathrm{O}^{\prime}, \mathrm{KU}\right.$ 159,000*, 159001*, 159002*, 159003*); Monteverde, Monteverde Cloud Forest Reserve, Sendero Chomogo, $\sim 1660 \mathrm{~m}\left[10^{\circ} 18^{\prime} \mathrm{N}, 84^{\circ} 48^{\prime} \mathrm{W}\right]$ (1o, KU 143402*). Puntarenas-Guanacaste border; Monteverde, Cerro Amigos, $1790 \mathrm{~m}\left[10^{\circ} 19^{\prime} \mathrm{N}, 84^{\circ} 48^{\prime} \mathrm{W}\right]$ (10*, 1\%, KU 143404*, 143405*).

Sigmodontomys alfari (29).-COLOMBIA: Caldas; Samaná, Río Hondo $\left[05^{\circ} 17^{\prime} \mathrm{N}, 75^{\circ} 15^{\prime} \mathrm{W}\right]$ (10’, FMNH 71639); Córdoba; Socorré, upper Río Sinú, $110 \mathrm{~m}$ [09 $\left.24^{\prime} \mathrm{N}, 75^{\circ} 49^{\prime} \mathrm{W}\right]$ (1o, 10’, FMNH 69192, 69195). COSTA RICA: Cartago; Perálta, El Sauce $\left[09^{\circ} 58^{\prime} \mathrm{N}, \quad 83^{\circ} 37^{\prime} \mathrm{W}\right.$ - for Perálta] (10’, AMNH
123305); Perálta, Santa Teresa (10*, AMNH 141877). HONDURAS: Gracias a Dios; Río Coco [14 $\left.45^{\prime} \mathrm{N}, 84^{\circ} 03^{\prime} \mathrm{W}\right]$ (20’0', USNM 392876, 392877). NICARAGUA: Matagalpa; Río Grande (10;, 1?, AMNH 28547, 28549). PANAMA: Bocas del Toro; Almirante $\left[09^{\circ} 18^{\prime} \mathrm{N}, 82^{\circ} 24^{\prime} \mathrm{W}\right] \quad\left(40^{\prime} 0^{\prime}\right.$, USNM 315996, 315997, 315998, 315999). Darién; Boca de Río Paya, Cana, 2000 ft [660 m] [07 $\left.55^{\prime} \mathrm{N}, 77^{\circ} 31^{\prime} \mathrm{W}\right]$ (1o, FMNH 53998); $1800 \mathrm{ft}[590 \mathrm{~m}]\left[07^{\circ} 55^{\prime} \mathrm{N}\right.$, $\left.77^{\circ} 31^{\prime} \mathrm{W}\right]\left(60^{\circ} \circ^{\prime}\right.$, USNM 178625, 178626, 178630 , 178631, 178632, 178633); Tacarcuna, $2650 \mathrm{ft}$ [870 m] [08 $\left.07^{\prime} \mathrm{N}, 77^{\circ} 17^{\prime} \mathrm{W}\right]$ (80’0', AMNH 37900, 37901, 37904, 37905, 37908, 37909, 37912, 37914); Tacarcuna Village, $3200 \mathrm{ft}[1050 \mathrm{~m}] \quad\left[08^{\circ} 05^{\prime} \mathrm{N}\right.$, $\left.77^{\circ} 17^{\prime} \mathrm{W}\right]$ (10’, USNM 310586).

Sigmodontomys aphrastus (6).-COSTA RICA: Alajuela; Monteverde, Monteverde Cloud Forest Reserve, Sendero Peñas Blancas, $1300 \mathrm{~m}\left[10^{\circ} 18^{\prime} \mathrm{N}\right.$, $\left.84^{\circ} 47^{\prime} \mathrm{W}\right]$ (10’, KU 161003). Puntarenas; Monteverde, Monteverde Cloud Forest Reserve, Sendero Brillante, $1550 \mathrm{~m}\left[10^{\circ} 18^{\prime} \mathrm{N}, 84^{\circ} 48^{\prime} \mathrm{W}\right]$ (1o, KU 159021). ECUADOR: Pichincha; Guarumos on the "W. slope of Mt. Pichincha, $4200 \mathrm{ft}$ " (10", MCZ 50396) [The specimen tag records the elevation of Guarumos as $4200 \mathrm{ft}$. Paynter \& Traylor (1977) and Paynter (1993) place Guarumos at 1500-2000 m $\left[00^{\circ} 04^{\prime} \mathrm{S}, 78^{\circ} 38^{\prime} \mathrm{W}\right]$; however, IGM (1972) places Guarumos at $2600 \mathrm{~m}\left[00^{\circ} 03^{\prime} \mathrm{S}, 78^{\circ} 38^{\prime} \mathrm{W}\right]$; Mindo, $4200 \mathrm{ft}[1380 \mathrm{~m}]\left[00^{\circ} 03^{\prime} \mathrm{N}, 78^{\circ} 48^{\prime} \mathrm{W}\right]$ (1o, UMMZ 155808) (Voss 1988). PANAMA: Chiriquí; 24 km NNE San Félix, ca. 1275-1325 m (20’0", USNM 541200, 541201). 